\title{
DAMPAK NILAI TUKAR DAN RISK-BASED BANK RATING TERHADAP PREDIKSI KONDISI PERBANKAN INDONESIA
}

\author{
Diana Kanya Prasidha \\ Setyo Tri Wahyudi \\ Fakultas Ekonomi dan Bisnis \\ Universitas Brawijaya Malang \\ J1. MT Haryono 165 Malang, Telp. 0341-551396 \\ Korespondensi: setyo81@gmail.com
}

\begin{abstract}
Model predictions to asses the problematic conditions in banking sectors need to be developed. It because by knowing early of systemic risks condition, policymakers can take anticipation actions. In this study, the financial ratios used are RiskProfile, Good Corporate Governance, Earning, and Capital (RGEC) rating based approach. The risk profile is proxied by the Non Performing Loan (NPL) which represented by the Net Open Position (PDN) for market risk, and Loan to Deposit Ratio (LDR) for liquidity risk. Meanwhile, good corporate governance aspect is not investigated since the aspect is more qualitative. Then, the profitability aspect proxied by the Return on Asset (ROA) and Net Interest Margin (NIM), while the capital aspect proxied by the Capital Adequacy Ratio (CAR). In this study added one macroeconomic variables, namely the Exchange Rates.

The study was conducted in 2009-2013 to predict and analyze the performance of the Indonesian banking sector, particularly for Private National Banks which are the most susceptible to problematic conditions. Using the logistic regression model, the results showed that the variables of NPL, PDN, ROA, and Exchange Rates are significantly effect on the probability of occurrence of the condition of troubled banks.
\end{abstract}

Keywords: Prediction Troubled Condition Bank, RGEC Rating, Exchange Rates.

QE Journal |Vol.04 - No.03 September 2015 - 122 


\section{PENDAHULUAN}

$B$

ank merupakan sektor penting yang memediasi antara masyarakat yang memiliki kelebihan dana dengan masyarakat yang memerlukan dana. Sektor keuangan, terutama di negara-negara berkembang masih didominasi oleh lembaga perbankan. Berdasarkan Laporan Kajian Stabilitas Keuangan (Maret 2014), industri perbankan masih memegang peranan dominan dalam sistem keuangan Indonesia. Pangsa pasar industri perbankan dalam sistem keuangan meningkat dari 77,9\% pada semester I 2013 menjadi 78,5\% pada semester II 2013. Disusul kemudian dengan Asuransi sebesar 10,1\%, Perusahaan Pembiayaan sebesar 6,7\%, Dana Pensiun sebesar 2,6\%, Bank Perkreditan Rakyat sebesar $1,2 \%$ dan peringkat komposisi aset lembaga keuangan tiga terbawah yaitu Pegadaian sebesar 0,5\%, Perusahaan Penjaminan serta Perusahaan Modal Ventura yang masing-masing sebesar $0,1 \%$ dari total komposisi aset lembaga keuangan.

Sektor perbankan juga merupakan sektor yang paling rentan terkena risiko sistemik yang bisa menggoyah stabilitas sistem keuangan. Riset yang dilakukan Lindgren et al (1996) dalam Prasetyo (2011) menunjukkan bahwa banyak negara yang perekonomiannya rusak sebagai akibat tidak sehatnya sektor perbankan. Kegagalan suatu bank khususnya yang bersifat sistemik akan mengakibatkan terjadinya krisis yang dapat mengganggu kegiatan suatu perekonomian. Pada tahun 2009, Bank Century yang merupakan leburan tiga bank (Bank CIC, Bank Denpac dan Pikko) ditetapkan sebagai bank gagal dan berpotensi sistemik akhirnya diputuskan untuk diselamatkan dan kini berganti nama menjadi Bank Mutiara. Pada saat itu Lembaga Penjamin Simpanan hanya memiliki kas Rp 14 triliun sedangkan terdapat 18 bank bermasalah dan 5 bank mirip Bank Century. 


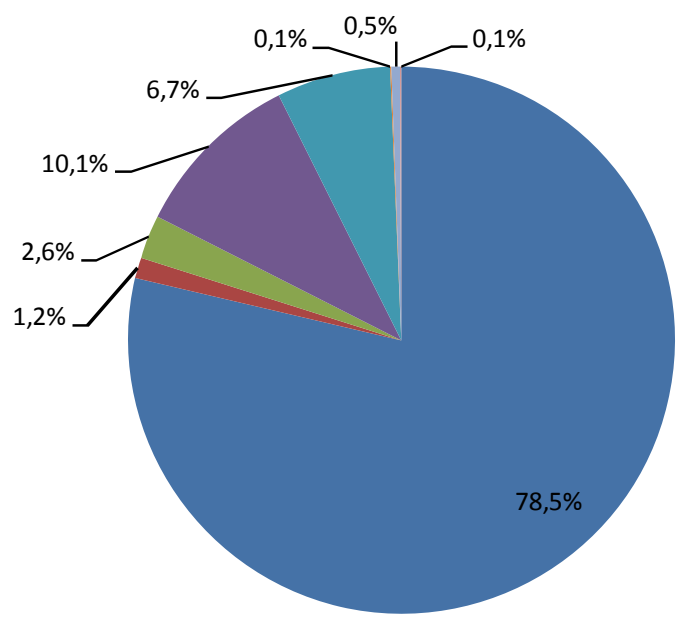

$$
\begin{aligned}
& \text { - Perbankan } \\
& \text { - BPR } \\
& \text { - Dana Pensiun } \\
& \text { - Asuransi } \\
& \text { - Perusahaan Pembiayaan } \\
& \text { - Perusahaan Penjaminan } \\
& \text { - Pegadaian } \\
& \text { - Perusahaan Modal Ventura }
\end{aligned}
$$

Sumber: Bank Indonesia (2014)

Gambar 1. Komposisi Aset Lembaga Keuangan

Kondisi bermasalah yang dialami perbankan umumnya hanya dialami oleh bank-bank umum swasta Indonesia dikarenakan bank umum swasta mengelola dan mendanai kegiatan mereka sendiri, sehingga bank-bank ini akan memiliki risiko sistemik yang lebih besar. Sebaliknya, kondisi berbeda ditunjukkan oleh bank persero yang telah dijamin kesehatannya dan tetap dalam pengawasan intensif pemerintah baik dari segi permodalan maupun kinerjanya. Namun tetap saja walaupun kondisi bermasalah cenderung selalu ditunjukkan oleh bank umum swasta, jika hal ini tidak mendapat perhatian serius dikhawatirkan kegagalan bank secara individu akan membawa dampak buruk kepada sistem perbankan 


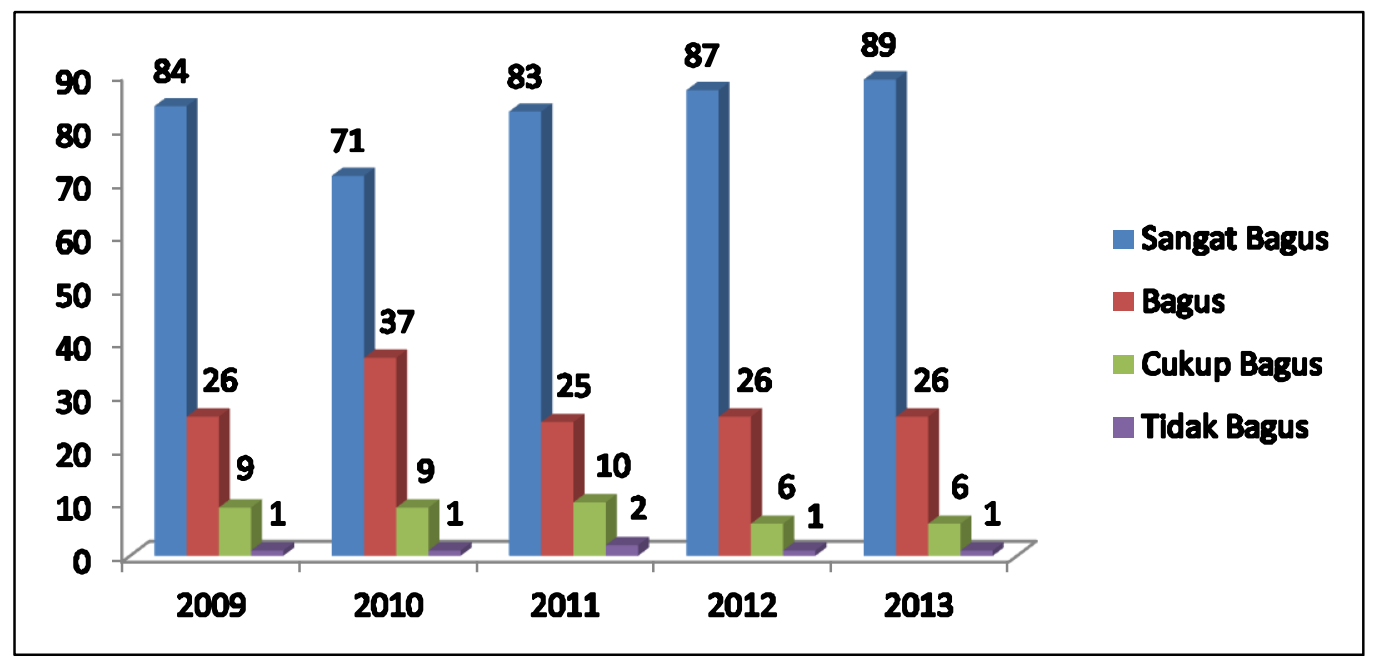

Sumber: Biro Riset Infobank (2014)

Gambar 2. Predikat Kinerja Bank Umum di Indonesia

secara keseluruhan. Kinerja kesehatan bank persero dan bank umum swasta nasional di tunjukkan oleh Gambar 3.

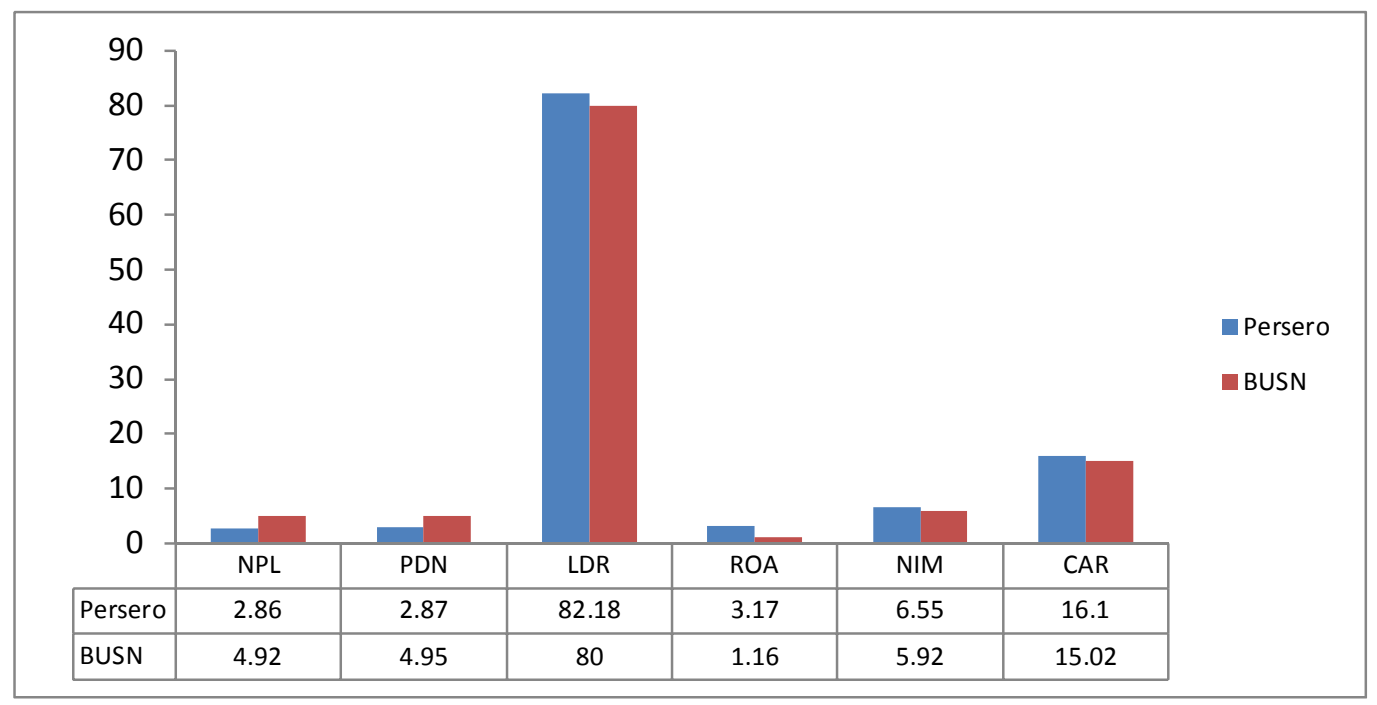

Sumber: Data Primer, 2015. Diolah

Gambar 3. Kinerja Kesehatan Bank Persero dan BUSN Tahun 2009-2013

Berdasarkan gambar 3, diketahui bahwa rata-rata kinerja dari Bank Persero dan Bank Umum Swasta Nasional (BUSN) dari segi NPL yang merupakan risiko terbesar perbankan, terlihat bahwa bank persero lebih unggul daripada BUSN dalam mengelola kredit macetnya. Begitu juga dengan QE Journal | Vol.04 - No.03 September 2015 - 125 
pengelolaan valuta asing yang dapat dilihat dari rasio PDN, bank persero juga memiliki risiko pasar yang lebih rendah dibanding BUSN. Selanjutnya pada aspek likuiditas, rentabilitas, dan permodalan, bank persero juga lebih unggul daripada BUSN yang dapat dilihat dari rata-rata rasio LDR, ROA, NIM, dan CAR yang menunjukkan rasio lebih tinggi selama tahun 2009-2013.

Dalam memprediksi suatu kebangkrutan atau dalam keadaan bermasalah dapat dilihat dari kinerja perbankan yang ditunjukkan oleh hasil penilaian kesehatan bank berdasarkan rasio keuangan. Bank Indonesia selaku bank sentral menetapkan pengukuran kinerja kesehatan bank dalam PBI No.13/1/PBI/2011 tentang Penilaian Tingkat Kesehatan Bank Umum yang berisi tentang tata cara penilaian kesehatan bank dengan pendekatan riskbased bank rating dengan melihat faktor-faktor penilaian yang terdiri dari profil risiko (risk profile) dimana NPL yang mewakili risiko kredit, PDN yang mewakili risiko pasar, dan LDR yang mewakili risiko likuiditas, good corporate governance tidak diteliti karena merupakan aspek dengan penilaian kualitatif, rentabilitas (earnings) yang diproksikan dengan rasio ROA dan NIM dan permodalan (capital) yang diproksikan dengan rasio CAR. Untuk memprediksi kondisi bermasalah perbankan tidak hanya dipicu oleh kondisi internal perbankan semata, tetapi juga adanya fluktuasi dan ketidakstabilan Makroekonomi. Pada penelitian ini ditambahkan variabel makroekonomi yaitu Nilai Tukar (Kurs) karena pada beberapa kondisi krisis perbankan di Indonesia diawali dengan krisis nilai tukar Rupiah (Rp) terhadap Dollar (USD). Naiknya nilai tukar tersebut menyebabkan inflasi yang berdampak pada peningkatan suku bunga yang akhirnya berpengaruh pada sektor perbankan.

\section{Teori Sinyal (Signalling Theory) dan Kebangkrutan Bank}

Teori sinyal menyatakan bagaimana sinyal mempengaruhi pasar melalui informasi perusahaan sehingga pasar dapat menilai sinyal tersebut dengan asumsi pribadi. Sinyal dapat berupa informasi atau promosi lain yang menyatakan bahwa perusahaan tersebut lebih unggul dibandingkan perusahaan lainnya. Agar terlihat lebih unggul maka perusahaan harus sebaik mungkin menjaga kualitasnya dan unik dalam artian tidak mudah ditiru oleh perusahaan lain (Krisnawati, 2014). Spence (1973) mengemukakan teori sinyal (signaling theory), yang menyatakan bahwa dengan memberikan suatu sinyal, pihak pengirim (pemilik informasi)

QE Journal | Vol.04 - No.03 September 2015 - 126 
berusaha memberikan informasi relevan yang dapat dimanfaatkan oleh pihak penerima. Indikasi lebih awal mengenai kondisi perbankan akan memungkinkan bank melakukan langkah-langkah antisipatif untuk mencegah agar krisis keuangan dapat diantisipasi, sehingga diharapkan dapat menjadi suatu tanda mengenai kondisi bank apakah sedang mengalami kondisi bermasalah atau tidak, serta dapat dijadikan dasar kebijakan untuk mengatasi masalah dan penyelamatan lebih dini dan dampak atau kerugian dapat diminimalkan (Hadad dkk, 2004).

Perusahaan yang mengalami kebangkrutan biasanya diawali dengan kondisi financial distress (kesulitan keuangan) terlebih dahulu, dimana perusahaan mengalami kesulitan likuiditas dan lebih parah lagi bila perusahaan tidak mampu menjalankan operasi dengan baik dan ini yang kemudian menyebabkan perusahaan bangkrut (Harianto dan Sudomo, 1998). Almilia dan Herdiningtyas (2005) menyatakan bahwa perusahaan yang mengalami financial distress adalah perusahaan yang selama beberapa tahun mengalami laba bersih operasi (net operation income) negatif.

Suatu bank dikatakan bermasalah jika bank yang bersangkutan mengalami kesulitan yang bisa membahayakan kelangsungan usahanya, kondisi usaha bank semakin menurun, yang ditandai dengan menurunnya permodalan, kualitas aset, likuiditas, serta pengelolaan bank yang tidak didasarkan prinsip kehati-hatian dan asas perbankan yang sehat. Berdasarkan OJKPedia (2014), bank bermasalah adalah Bank yang mempunyai rasio atau nisbah kredit tak lancar yang tinggi apabila dibandingkan dengan modalnya dan Bank yang dari hasil pemeriksaan nilai CAMEL-nya berada pada posisi empat (kurang sehat) dan lima (tidak sehat) pada daftar urutan kondisi bank, penilaian tersebut tidak disebarluaskan ke masyarakat; bank bermasalah akan lebih sering diperiksa daripada bank yang berkondisi sehat.

\section{Risk-Based Bank Rating}

Berdasarkan PBI No. 13/1/PBI/2011 Tentang Penilaian Tingkat Kesehatan Bank Umum, Bank Indonesia telah menetapkan sistem penilaian Tingkat Kesehatan Bank berbasis risiko menggantikan dan menyempurnakan penilaian CAMELS yang dulu diatur dalam PBI No.6/10/PBI/2004. Penilaian tingkat kesehatan bank dengan menggunakan pendekatan berdasarkan risiko (Risk-Based Bank Rating) merupakan penilaian yang 
komprehensif dan terstruktur yang dikenal dengan rating RGEC yang meliputi Risk Profile, Good Corporate Governance yaitu kinerja yang meliputi penerapan tata kelola yang baik, Earning dan Capital.

\section{Risiko Kredit}

Menurut Siamat (2005), Non Performing Loan merupakan presentase jumlah kredit bermasalah (dengan kriteria kurang lancar, diragukan dan macet) terhadap total kredit yang disalurkan bank. Semakin tinggi rasio ini maka akan semakin buruk kualitas kredit bank yang menyebabkan jumlah kredit bermasalah semakin besar, maka kemungkinan suatu bank dalam kondisi bermasalah semakin besar (Almilia dan Herdaningtyas, 2005). Kredit dalam hal ini adalah kredit yang diberikan kepada pihak ketiga tidak termasuk kredit kepada bank lain. Rasio ini dirumuskan sebagai berikut (Surat Edaran BI Nomor 13/24/DPNP tanggal 25 Oktober 2011):

NPL $=\frac{\text { Kredit Bermasalah }}{\text { Total Kredit }} \times 100 \%$

\section{Risiko Pasar}

Berdasarkan Surat Edaran BI Nomor 13/24/DPNP, indikator yang digunakan untuk mengukur Risiko Pasar yaitu Posisi Devisa Neto (PDN). Semakin tinggi rasio ini maka akan semakin berisiko suatu bank karena tidak bisa menjaga pengelolaan manajemen valuta asing dengan memonitor perdagangan valuta asing dalam posisi yang terkendali. Dengan kondisi yang sedemikian rupa tentunya prediksi kondisi bermasalah bank juga akan meningkat pula. Rasio ini dirumuskan sebagai berikut (Surat Edaran BI Nomor 13/24/DPNP tanggal 25 Oktober 2011):

PDN $=\frac{\begin{array}{c}(\text { Aktiva }+ \text { Rek. Adm. Aktiva })- \\ (\text { Pasiva }+ \text { Rek. Adm. Pasiva })\end{array}}{\text { Total Modal }} \times 100 \%$

\section{Risiko Likuiditas}

Menurut Almilia dan Herdiningtyas (2005), rasio LDR (Loan to Deposit Ratio) digunakan untuk menilai likuiditas suatu bank yang dengan cara membagi jumlah kredit yang diberikan oleh bank terhadap dana pihak ketiga. Rasio LDR menunjukkan tingginya kredit yang disalurkan dari total dana pihak ketiga yang dihimpun. Semakin besar rasio ini menunjukkan semakin rendahnya tingkat likuiditas yang dimiliki bank sehingga dapat meningkatkan potensi terjadinya kondisi bermasalah bank, karena bank 
tidak memiliki cukup dana untuk memenuhi penarikan dana pihak ketiga dan terlalu banyak menyalurkan kredit yang bisa meningkatkan risiko gagal bayar dan berdampak sistemik. Rasio ini dirumuskan sebagai berikut (Surat Edaran BI Nomor 13/24/DPNP tanggal 25 Oktober 2011) :

$\mathrm{LDR}=\frac{\text { Pendanaan Non Inti }(\text { Total Kredit })}{\text { Total Pendanaan }(\text { Dana Pihak Ketiga })} \times 100 \%$

\section{Profitabilitas}

Return On Assets (ROA) merupakan rasio yang digunakan untuk mengukur kemampuan manajemen bank dalam memperoleh profitabilitas dan mengelola tingkat efesiensi usaha bank secara keseluruhan. Semakin besar nilai rasio ini menunjukkan tingkat rentabilitas usaha bank semakin baik atau sehat (Prasnugraha, 2009). Semakin tinggi nilai ROA, semakin efektif pula pengelolaan aktiva perusahaan dan semakin kecil prediksi bank mengalami kondisi yang bermasalah. Rasio ini dirumuskan sebagai berikut (Surat Edaran BI Nomor 13/24/DPNP tanggal 25 Oktober 2011) :

$\mathrm{ROA}=\frac{\text { Laba sebelu mPajak }}{\text { Rata-rata } \text { Total Aset }} \times 100 \%$

\section{Rentabilitas}

Net Interest Margin (NIM) menggambarkan tingkat jumlah pendapatan bunga bersih yang diperoleh dengan menggunakan aktiva produktif yang dimiliki oleh bank, jadi semakin besar nilai NIM maka akan semakin besar pula keuntungan yang diperoleh dari pendapatan bunga dan akan berpengaruh pada tingkat kesehatan bank (Hakim, 2013). Rasio ini dirumuskan sebagai berikut (Surat Edaran BI Nomor 13/24/DPNP tanggal 25 Oktober 2011) :

$\mathrm{NIM}=\frac{\text { Pendapatan Bu ngaBersih }}{\text { Rata-rata Total Aset Produ ktif }} \times 100 \%$

\section{Permodalan}

Apabila Capital Adequacy Ratio yang dimiliki semakin rendah berarti semakin kecil modal bank yang dimiliki untuk menanggung aktiva beresiko, sehingga semakin besar kemungkinan bank akan mengalami kondisi bermasalah karena modal yang dimiliki bank tidak cukup menanggung penurunan nilai aktiva beresiko, dan juga sebaliknya jika CAR yang tinggi berarti modal yang dimiliki untuk menanggung aktiva resiko juga lebih tinggi sehingga semakin rendah mengalami kondisi QE Journal | Vol.04 - No.03 September 2015 - 129 
bermasalah karena modal yang dimiliki bank semakin besar (Martharini 2012). Rasio ini dirumuskan sebagai berikut (Surat Edaran BI Nomor 13/24/DPNP tanggal 25 Oktober 2011):

$$
\mathrm{CAR}=\frac{\text { Modal Bank }}{\text { ATMR }} \times 100 \%
$$

\section{METODE PENELITIAN}

Populasi dalam penelitian ini adalah seluruh Bank Umum Swasta Nasional Go Public dalam kurun waktu 2009-2013 yaitu sebanyak 24 perusahaan. Dari populasi yang ada akan diambil sampel dengan menggunakan teknik purposive sampling, karena informasi yang dibutuhkan dapat diperoleh dari satu kelompok sasaran tertentu yang mampu memberikan informasi dan memenuhi kriteria penelitian (Ferdinand, 2007). Kriteria perusahaan perbankan yang memenuhi sebagai sampel adalah (1) Bank Umum Swasta Nasional (BUSN) yang mempublikasikan laporan keuangan dan data laporan keuangan tersedia lengkap secara keseluruhan terpublikasi selama lima tahun berturut-turut pada periode tahun 2009-2013 yang disampaikan ke Otoritas Jasa Keuangan; (2) Laporan keuangan harus mempunyai tahun buku yang berakhir 31 Desember dan tersedia rasio-rasio keuangan yang mendukung penelitian; (3) Bank yang dijadikan sampel terbagi menjadi dua kategori, yaitu :

1) Bank Tidak Bermasalah, yaitu : (i) Bank-bank yang tidak masuk program penyehatan perbankan dan tidak dalam pengawasan khusus. Bank-bank tersebut masih beroperasi sampai 31 Desember 2013. (ii) Bank-bank tersebut tidak mengalami kerugian pada tahun 2009-2013;

2) Bank Bermasalah, yaitu : (i) Bank yang menderita kerugian dalam periode pengamatan 2009-2013. (ii) Bank yang mempunyai rasio atau nisbah kredit tak lancar yang tinggi apabila dibandingkan dengan modalnya dan Bank yang dari hasil pemeriksaan nilai CAMEL-nya berada pada posisi empat (kurang sehat) dan lima (tidak sehat) (OJKPedia, 2014); (4) Jumlah sampel yang akan diobservasi berjumlah genap.

Dari proses seleksi sampel dengan kriteria didapatkan sejumlah 12 sampel yang memenuhi kriteria untuk penelitian yang akan digunakan, yaitu 6

QE Journal | Vol.04 - No.03 September 2015 - 130 
bank yang termasuk dalam kondisi bermasalah dan 6 bank yang tidak termasuk dalam kondisi bermasalah (Tabel 1).

Tabel 1. Sampel Penelitian

\begin{tabular}{clcl}
\hline No & \multicolumn{1}{c}{ Nama Bank } & No & \multicolumn{1}{c}{ Nama Bank } \\
\hline $\mathbf{1 .}$ & PT. Bank Internasional Indonesia & 7. & PT. Bank Central Asia Tbk. \\
& Tbk. & & \\
2. & PT. MNC International Bank Tbk. & $\mathbf{8 .}$ & PT. Bank CIMB Niaga Tbk. \\
3. & PT. Bank Mutiara Tbk. & $\mathbf{9 .}$ & PT. Bank Mega Tbk. \\
4. & PT. Bank Nusantara Parahyangan & $\mathbf{1 0 .}$ & PT. Pan Indonesia Bank Tbk \\
& Tbk. & & \\
5. & PT. Bank Pundi Tbk. & $\mathbf{1 1 .}$ & PT. Bank Permata Tbk. \\
$\mathbf{6 .}$ & PT. Bank QNB Kesawan Tbk. & $\mathbf{1 2 .}$ & PT. Bank Tabungan Pensiun Nasional \\
& & & Tbk. \\
\hline
\end{tabular}

Sumber: Bursa Efek Indonesia (2014)

Dalam penelitian ini digunakan analisis regresi logistik (Logistic Regression Analysis) untuk menguji pengaruh rasio keuangan RGEC dan nilai tukar terhadap probabilitas terjadinya kondisi bermasalah pada sektor perbankan. Adapun model dasar dari regresi logistik dari penelitian ini dapat dirumuskan sebagai berikut (Widarjono, 2009):

$\ln \frac{P_{i}}{1-P_{i}}=Z_{i}=\beta_{0}+\beta_{1} \mathrm{X}_{1}+\beta_{2} \mathrm{X}_{2}+\ldots+\beta_{\mathrm{k}} \mathrm{X}_{\mathrm{ik}}$

Keterangan :

$\ln \frac{P_{i}}{1-P_{i}} \quad$ : Rasio logaritma natural dari probabilitas kondisi bermasalah.

$\beta_{0} \quad$ : Konstanta.

$\beta_{1} \ldots \beta_{\mathrm{k}}$ : Koefisien Regresi.

$\mathrm{X}_{\mathrm{ik}} \quad$ : Nilai variabel independen dari observasi ke $\mathrm{i}$, dimana $\mathrm{k}=1,2, \ldots, \mathrm{k}$.

Adapun model analisis regresi logistik yang digunakan pada penelitian ini dapat dirumuskan sebagai berikut:

$\ln \frac{P_{i}}{1-P_{i}}=Z_{i}=\beta_{0}+\beta_{1} \mathrm{X}_{1 \mathrm{i}}+\beta_{2} \mathrm{X}_{2 \mathrm{i}}+\beta_{3} \mathrm{X}_{3 \mathrm{i}}+\beta_{4} \mathrm{X}_{4 \mathrm{i}}+\beta_{5} \mathrm{X}_{5 \mathrm{i}}+\beta_{6} \mathrm{X}_{6 \mathrm{i}}+\beta_{7} \mathrm{X}_{7 \mathrm{i}}$

dimana :

$\ln \frac{P_{i}}{1-P_{i}} \quad$ : Rasio logaritma natural dari probabilitas kondisi bermasalah.

QE Journal | Vol.04 - No.03 September 2015 - 131 


$$
\begin{array}{ll}
\beta_{0} & : \text { Konstanta. } \\
\beta_{1} \ldots \beta_{\mathrm{k}} & : \text { Koefisien Regresi. } \\
\mathrm{X}_{1} & : \text { Non Performing Loan (NPL) } \\
\mathrm{X}_{2} & : \text { Posisi Devisa Neto (PDN) } \\
\mathrm{X}_{3} & \text { : Loan to Deposit Ratio (LDR) } \\
\mathrm{X}_{4} & : \text { Return On Asset (ROA) } \\
\mathrm{X}_{5} & : \text { Net Interest Margin (NIM) } \\
\mathrm{X}_{6} & \text { : Capital Adequacy Ratio (CAR) } \\
\mathrm{X}_{7} & \text { : Nilai Tukar }
\end{array}
$$

\section{HASIL DAN PEMBAHASAN}

Analisis awal yang dilkukan sebelum pengujian hipotesis adalah menilai overall fit model terhadap data penelitian. Beberapa test statistic diberikan untuk menilai hal ini. Menilai model fit dapat dilakukan dengan menggunakan fungsi likelihood.

Tabel 2. Menilai Model Fit

\begin{tabular}{lll}
\hline Pengujian & Keterangan & Nilai \\
\hline -2 LL Block Number & -2 LL Block Number 0 & 73,332 \\
& -2 LL Block Number 1 & 56,786 \\
Cox E Snell's R Square & Cox E Snell's R Square & 0,612 \\
Negelkerke's R Square & Negelkerke's R Square & 0,868 \\
Hosmer and Lemeshow Test & Chi Square & 8,459 \\
& Sig. & 0,390 \\
\hline
\end{tabular}

Sumber: Data Primer, 2015. Diolah

Untuk menilai model fit adalah berdasarkan pada fungsi Likelihood. Likelihood L dari model adalah probabilitas bahwa model yang dihipotesiskan menggambarkan data input (Almilia dan Herdinigtyas, 2005). Untuk pengujian L ditransformasikan menjadi -2LogL. Berdasarkan tabel di atas, hasil menunjukan nilai -2LogL Block Number $=0$ adalah 73,332 kemudian terjadi penurunan nilai-2LogL Block Number $=1$ menjadi 56,786, maka dapat disimpulkan bahwa model tersebut menunjukan model regresi yang baik. Jika dilihat dari nilai Cox \& Snell's $R$ Square sebesar 0,612 dan Nagelkerke's $R$ Square sebesar 0,868 dapat menggambarkan bahwa variabel independen dalam model empiris mampu menerangkan perubahan probabilitas terjadinya kondisi bermasalah sebesar $86,8 \%$, sedangkan $13,2 \%$ sisanya dipengaruhi oleh variabel lain di luar model empiris. Nilai statistik 
Hosmer \& Lemeshow Test sebesar 8,459 dengan tingkat probabilitas signifikansi sebesar 0,390 . Dengan tingkat signifikansi lebih besar dari tingkat $\alpha$ sebesar 0,10 maka model mampu memprediksi nilai observasinya atau dapat dikatakan bahwa model dapat diterima karena cocok dengan data observasinya.

Berdasarkan hasil perhitungan skor Z maka dapat diketahui hasil probabilitas masing-masing bank dan distribusi hasil peluang untuk menunjukkan kecenderungan kondisi bermasalah pada perbankan yang secara lengkap dapat disajikan pada Tabel 3.

Berdasarkan Tabel 3 dapat dilihat bahwa dari 60 data hasil penelitian dapat diketahui bahwa terdapat 42 bank yang tidak mengalami permasalahan perbankan dengan ketepatan prediksi sebesar 100\%. Sebanyak 18 data penelitian yang masuk dalam kategori bank yang bermasalah, setelah diobservasi terdapat 2 bank yang masuk dalam pengelompokan data yang tidak memiliki kondisi bermasalah dan sebanyak 16 data penelitian dalam kelompok bank yang memiliki permasalahan perbankan. Sebesar $88,9 \%$ dari 18 data penelitian dapat dikelompokkan secara tepat oleh model. Berdasarkan hasil analisis tersebut maka secara umum model yang diperoleh dapat diandalkan dalam memprediksi kondisi bermasalah pada perbankan sebesar 96,7\% karena dapat menentukan keputusan prediksi atas kondisi bermasalah pada perbankan.

Hasil analisis menunjukkan hanya variabel Non Performing Loan (NPL), Posisi Devisa Neto (PDN), Return On Asset (ROA) dan Nilai Tukar (Kurs) yang memiliki pengaruh signifikan terhadap probabilitas terjadinya kondisi bermasalah pada perbankan dengan tingkat kepercayaan 90\% $(\alpha=$ $10 \%$ ). Dari nilai statistik Wald diketahui bahwa variabel Non Performing Loan (NPL) memiliki kontribusi dominan terhadap probabilitas terjadinya kondisi bermasalah pada perbankan dengan nilai statistik Wald sebesar 4,299 . 
Tabel 3. Tabel Klasifikasi

\begin{tabular}{lclll}
\hline \multirow{2}{*}{ Observed } & \multicolumn{2}{l}{ Predicted } \\
\cline { 2 - 4 } & \multicolumn{2}{l}{ Prediksi Kondisi Bermasalah } & Percentage Correct \\
\cline { 2 - 4 } & & $\mathbf{0}$ & $\mathbf{1}$ & 100,0 \\
\hline Prediksi Kondisi & $\mathbf{0}$ & 42 & 16 & 88,9 \\
Bermasalah & $\mathbf{1}$ & 2 & & 96,7 \\
Overall Percentage & & & &
\end{tabular}

Sumber: Data Primer, 2015. Diolah

Tabel 4. Koefisien Regresi Logistik

\begin{tabular}{llll}
\hline Keterangan & B & Wald & Sig. \\
\hline NPL $\left(\mathbf{X}_{\mathbf{1}}\right)$ & 3,227 & 4,299 & 0,038 \\
PDN $\left(\mathbf{X}_{2}\right)$ & $-0,713$ & 3,980 & 0,046 \\
LDR $\left(\mathbf{X}_{3}\right)$ & 0,066 & 0,914 & 0,339 \\
ROA $\left(\mathbf{X}_{4}\right)$ & $-4,113$ & 3,666 & 0,056 \\
NIM $\left(\mathbf{X}_{5}\right)$ & 0,411 & 0,633 & 0,426 \\
CAR $\left(\mathbf{X}_{6}\right)$ & 0,105 & 1,220 & 0,269 \\
Nilai Tukar $\left(\mathbf{X}_{7}\right)$ & 0,003 & 3,372 & 0,066 \\
Constant & $-43,647$ & 3,648 & 0,056 \\
\hline
\end{tabular}

Sumber: Data Primer, 2015. Diolah

Berdasarkan hasil analisis regresi logistik pada tabel 4, maka model analisis regresi logistik yang terbentuk yaitu:

$Z_{i}=-43.647+3.227 X_{1}-0.713 X_{2}+0.066 X_{3}-4.113 X_{4}+0.411 X_{5}+$ $0.105 X_{6}+0.003 X_{7}$

\section{Implikasi dan Pembahasan Hasil}

Berdasarkan hasil estimasi dengan regresi logit dapat diketahui bahwa risiko kredit yang diproksikan dengan rasio Non Performing Loan mempunyai koefisien sebesar 3,227. Hal ini berarti apabila variabelvariabel lain dianggap konstan maka kenaikan Non Performing Loan sebesar 1 persen akan menyebabkan peningkatan secara rata-rata pada probabilitas terjadinya kondisi bermasalah bank sebesar 3,22. Risiko kredit merupakan risiko terbesar dalam sistem perbankan Indonesia dan berdampak secara sistemik terhadap bank-bank lainnya sebagai pemicu utama kegagalan perbankan. Prediksi kondisi bermasalah pada bank menunjukkan bahwa dengan mengukur tingkat bermasalahnya suatu kredit, secara langsung dapat menentukan prediksi kondisi bermasalah yang terjadi pada suatu 
bank. Rasio ini menunjukkan kemampuan kolektibilitas sebuah bank dalam mengumpulkan kembali kredit yang dikeluarkan oleh bank sampai lunas. Semakin tinggi rasio ini maka akan semakin buruk kualitas kredit bank yang menyebabkan jumlah kredit bermasalah semakin besar, maka kemungkinan bank memiliki potensi kondisi yang bermasalah semakin besar.

Risiko pasar yang diproksikan dengan rasio Posisi Devisa Neto mempunyai koefisien sebesar -0,713. Hal ini berarti apabila variabelvariabel lain dianggap konstan maka penurunan Posisi Devisa Neto sebesar 1 persen akan menyebabkan peningkatan secara rata-rata pada probabilitas terjadinya kondisi bermasalah bank sebesar 0,71. Posisi Devisa Neto (PDN) menunjukkan tingkat kepatuhan bank terhadap regulasi Bank Indonesia dengan batas maksimum 20\%. Bank yang memiliki PDN di atas $20 \%$ adalah bank yang spekulatif, berisiko valas tinggi dan tidak patuh terhadap regulasi ini (Taswan, 2010). Pertumbuhan Posisi Devisa Neto selama tahun 2009-2013 secara umum mengalami peningkatan. Ketika bank dapat memanajemen risiko valasnya dengan baik akan berakibat pada peningkatan pengelolaan modal nya. Posisi Devisa Neto dapat memberikan gambaran mengenai sejauh mana kemampuan permodalan perbankan dalam pengelolaan manajemen valuta asing, sehingga semakin kecil rasio tersebut maka semakin besar kemampuan permodalan perbankan dari risiko pasar dan permasalahan yang akan dihadapi perbankan.

Risiko likuiditas yang diproksikan dengan rasio Loan to Deposit Ratio mempunyai koefisien sebesar 0,066. Hal ini berarti apabila variabelvariabel lain dianggap konstan maka kenaikan Loan to Deposit Ratio sebesar 1 persen tidak akan menyebabkan peningkatan secara rata-rata pada probabilitas terjadinya kondisi bermasalah bank. Kondisi Loan to Deposit Ratio selama tahun 2009-2013 menunjukkan tren yang positif. Kondisi Loan to Deposit Ratio yang semakin baik ini tetap berada pada batas yang diwajibkan Bank Indonesia yaitu 78-92\%. Dikarenakan kinerja Bank sudah baik dalam menjalankan manajemen atas risiko likuiditas mereka sehingga diprediksikan tidak akan membawa Bank ke arah yang bermasalah. Hal ini ditunjukkan pula oleh tingkat penyaluran kredit yang baik dan tepat sehingga tidak menyebabkan kredit yang disalurkan tersebut menjadi kredit yang bermasalah (macet).

QE Journal |Vol.04 - No.03 September 2015 - 135 
Profitabilitas yang diproksikan dengan rasio Return On Asset mempunyai koefisien sebesar -4,113. Hal ini berarti apabila variabel-variabel lain dianggap konstan maka penurunan Return On Asset sebesar 1 persen akan menyebabkan peningkatan secara rata-rata pada probabilitas terjadinya kondisi bermasalah bank sebesar 4,11. Mampunya Return On Asset untuk memprediksi kondisi bermasalah perbankan dapat memberikan gambaran mengenai sejauh mana kemampuan bank untuk menghasilkan keuntungan dari total aktiva yang dimiliki. Semakin tinggi ROA maka semakin tinggi pula kemampuan bank untuk menghindari permasalahan perbankan yang dapat terjadi. Rendahnya kemampuan dalam peningkatan keuntungan bank atas penggunaan aktiva yang dimiliki menjadikan kemampuan bank juga mengalami penurunan dan kemungkingan terjadinya permasalahan perbankan juga tinggi.

Rentabilitas yang diproksikan dengan rasio Net Interest Margin mempunyai koefisien sebesar 0,411. Hal ini berarti apabila variabel-variabel lain dianggap konstan maka kenaikan Net Interest Margin sebesar 1 persen tidak akan menyebabkan peningkatan secara rata-rata pada probabilitas terjadinya kondisi bermasalah bank. Perkembangan Net Interest Margin selama tahun 2009-2013 menunjukkan tren yang menurun, tetapi masih jauh di atas batas minimum yang ditetapkan Bank Indonesia. Pencapaian NIM yang cukup baik ini juga didukung oleh pengelolaan likuiditas bank yang baik. Sudah cukup baiknya kinerja Net Interest Margin karena sudah baik pula pengelolaan likuiditas bank atau rasio dana yang dihimpun dan dana yang disalurkan. Loan to Deposit Ratio perbankan menunjukkan tren yang meningkat yang berarti bahwa pengelolaan Dana Pihak Ketiga sudah baik, dan penyaluran kredit tidak berlebihan masing seimbang dengan jumlah yang dihimpun. Kondisi LDR yang baik mendukung peningkatan pendapatan bunga bank, sehingga berdampak pada stabilnya angka NIM yang menghindarkan perbankan dari kondisi yang bermasalah.

Permodalan yang diproksikan dengan Capital Adequacy Ratio mempunyai koefisien sebesar 0,105. Hal ini berarti apabila variabel-variabel lain dianggap konstan maka kenaikan Capital Adequacy Ratio sebesar 1 persen tidak akan menyebabkan peningkatan secara rata-rata pada probabilitas terjadinya kondisi bermasalah bank. Bank Indonesia menetapkan nilai standar untuk rasio CAR sebesar $8 \%$. Faktor permodalan yang dimiliki oleh perbankan secara umum sangat baik dengan rata-rata sebesar 15,103\% 
jauh di atas $8 \%$ batas yang ditetapkan Bank Indonesia. Sehingga secara realitas bisnis, bank yang profitable tidak harus dengan CAR sebesar $8 \%$, yang terpenting adalah kepercayaan masyarakat terhadap dunia perbankan. Selain itu saat ini terdapat Lembaga Penjamin Simpanan (LPS) yang akan menjamin dana nasabah yang disimpan di Perbankan. Sejalan dengan Peraturan Bank Indonesia No 13/3/PBI/2011 tentang Penetapan Status dan Tindak Lanjut Pengawasan Bank, bank bermasalah yang memiliki modal $<8 \%$ akan dan telah dianjurkan Bank Indonesia untuk melakukan merger atau akuisisi yang akhirnya menyebabkan tambahan modal lebih besar sehingga faktor permodalan tidak dapat memprediksi terjadinya kondisi bermasalah pada perbankan Indonesia.

Nilai Tukar mempunyai koefisien 0,003. Hal ini berarti apabila variabelvariabel lain dianggap konstan maka kenaikan Nilai Tukar sebesar 1 persen akan menyebabkan peningkatan secara rata-rata pada probabilitas terjadinya kondisi bermasalah bank sebesar 0,003. Pelemahan nilai tukar juga akan berdampak pada psikologi nasabah. Hal ini menyebabkan nasabah yang memiliki dana di bank mulai mencairkan simpanan valas mereka dan merealisasikan keuntungan. Nasabah juga menjadi panik dan menarik dana dari bank (bank runs) karena khawatir dana mereka akan bermasalah di bank. Kondisi ini yang akan menyebabkan bermasalahnya suatu perbankan.

\section{Implikasi Model Temuan}

Berdasarkan hasil analisis data yang telah dilakukan maka dapat diperoleh model persamaan yang berbeda, dimana perbedaan tersebut ditunjukkan dari persamaan yang terbentuk. Dari hasil analisis dapat diketahui bahwa persamaan yang terbentuk sebagai berikut, untuk selanjutnya disebut sebagai $\mathrm{Z}$ riil $\left(\mathrm{Z}^{*}\right)$ :

$Z_{i}=-43.647+3.227 X_{1}-0.713 X_{2}+0.066 X_{3}-4.113 X_{4}+0.411 X_{5}+$ $0.105 X_{6}+0.003 X_{7}$

Dengan melakukan penambahan tahun pengamatan yaitu tahun 2014 maka persamaan yang terbentuk yaitu sebagai berikut, untuk selanjutnya disebut sebagai $Z$ temuan $(\hat{Z})$ :

$$
\begin{aligned}
& Z_{i}=-8,517+1,094 X_{1}-0,211 X_{2}+0,063 X_{3}-2,153 X_{4}-0,163 X_{5}+ \\
& 0,025 X_{6}+0,0001 X_{7}
\end{aligned}
$$


Hasil perbandingan persamaan yang terbentuk maka terdapat perbedaan dari hasil koefiesiennya antara $\mathrm{Z}$ riil $\left(\mathrm{Z}^{*}\right)$ dan $\mathrm{Z}$ temuan $(\hat{\mathrm{Z}})$, yaitu pada variabel Nilai Tukar dan Net Interest Margin (NIM). Setelah menambah tahun pengamatan yaitu tahun 2014 implikasi model temuan yang terjadi adalah penurunan atas besarnya koefisien logistik dari variabel tersebut, penurunan ini memberikan sinyal bahwa perubahan nilai tukar tidak memberikan dampak secara langsung terhadap probabilitas terjadinya kondisi bermasalah pada bank. Hasil tersebut juga didukung oleh variabel Posisi Devisa Neto yang nilainya sangat bergantung pada fluktuasi nilai tukar mata uang. Posisi Devisa Neto cenderung mengalami penurunan selama tahun 2009-2014 yang menunjukkan terjadinya penguatan kondisi secara internal dalam hal ini Posisi Devisa Neto suatu bank, dan pihak bank mengalami peningkatan dalam pengelolaan manajemen risiko valuta asing.

Implikasi model temuan lain yang terjadi setelah ditambahkan pengamatan tahun 2014 adalah perubahan tanda dari koefisien variabel Net Interest Margin (NIM). Hasil ini sesuai dengan penelitian Almilia dan Herdiningtyas (2005) yang mengemukakan bahwa rasio NIM (Net Interest Margin) mempunyai pengaruh negatif terhadap prediksi kondisi bermasalah bank. Artinya semakin besar rasio ini maka, kemungkinan suatu bank dalam kondisi bermasalah semakin kecil. NIM berpengaruh negatif karena semakin besar rasio ini maka semakin meningkat pendapatan bunga atas aktiva produktif yang dikelola bank, sehingga kemungkinan suatu bank dalam mengalami kondisi bermasalah semakin kecil.

\section{SIMPULAN DAN SARAN}

Berdasarkan hasil penelitian dan pembahasan yang telah dilakukan, maka kesimpulan yang dapat diambil adalah:

1. Non Performing Loan (NPL) dapat digunakan untuk memprediksi potensi terjadinya kondisi bermasalah bank. Rasio ini merupakan rasio yang paling dominan dalam memprediksi kondisi bermasalah bank. Semakin tinggi rasio ini maka akan semakin buruk kualitas kredit bank yang menyebabkan jumlah kredit bermasalah semakin besar dan menurunkan kemampuan dalam pencapaian rasio keuntungan. Hal ini dikarenakan jenis risiko ini merupakan risiko terbesar (sistemik) dalam 
sistem perbankan Indonesia dan dapat menjadi penyebab utama kegagalan bank.

2. Posisi Devisa Neto (PDN) dapat digunakan untuk memprediksi terjadinya kondisi bermasalah bank. Dengan semakin rendahnya Posisi Devisa Neto (PDN) maka semakin tinggi kemampuan bank meminimalisir potensi terjadinya kondisi bermasalah pada bank. Hal ini menunjukkan bahwa risiko pasar yang akan ditanggung oleh bank atas pengelolaan manajemen valuta asing juga semakin rendah dan meminimalisir potensi terjadinya kondisi bermasalah dikarenakan perubahan nilai tukar yang dapat berubah sewaktu-waktu dalam jumlah besar dapat membuat gangguan yang dapat berakibat fatal bagi bank.

3. Loan to Deposit Ratio (LDR) tidak dapat memprediksi terjadinya kondisi bermasalah bank. Kondisi Loan to Deposit Ratio selama tahun pengamatan menunjukkan tren yang meningkat didukung dengan rendahnya kredit macet yang terjadi. Hal ini dapat memberikan gambaran mengenai sejauh mana bank mampu mengendalikan dana yang dipinjamkan kepada nasabah sehingga kontribusi yang diperoleh bank atas pemberian kredit yaitu berupa pendapatan bunga meningkat.

4. Return On Asset (ROA) dapat memprediksi terjadinya kondisi bermasalah bank. Semakin tinggi Return On Asset (ROA) sebagai aspek rentabilitas perbankan maka semakin tinggi pula kemampuan bank untuk menghindari permasalaha nperbankan yang dapat terjadi. Rendahnya kemampuan dalam peningkatan keuntungan bank atas penggunaan aktiva yang dimiliki menjadikan kemampuan bank juga mengalami penurunan dan kemungkingan terjadinya permasalahan perbankan juga tinggi. Semakin tingginya rasio Return On Asset (ROA) akan semakin menurunkan kondisi bermasalah pada perbankan.

5. Net Interest Margin (NIM) tidak dapat memprediksi terjadinya kondisi bermasalah bank. Kondisi Net Interest Margin selama tahun 2009-2013 menunjukkan peningkatan dikarenakan tingginya angka penyaluran kredit dan rendahnya kredit yang bermasalah (macet). Hal tersebut menunjukkan pendapatan bunga yang didapatkan bank dari debitur semakin meningkat, sehingga kemampuan rentabilitas bank dalam 
bentuk pendapatan bunga menjadi stabil dan menjauhkan bank dari potensi terjadinya kondisi yang bermasalah.

6. Capital Adequacy Ratio (CAR) tidak dapat memprediksi potensi terjadinya kondisi bermasalah bank. Hal ini terjadi dikarenakan bankbank yang mengalami kekurangan modal sudah pasti akan dianjurkan melakukan tindakan lebih lanjut yaitu dimerger atau diakusisi, akhirnya menyebabkan tambahan modal lebih besar sehingga faktor permodalan tidak dapat memprediksi kondisi bermasalah pada perbankan Indonesia.

7. NilaiTukar (Kurs) dapat digunakan untuk memprediksi potensi terjadinya kondisi bermasalah bank. Semakin tinggi nilai tukar maka akan meningkatkan permasalahan perbankan pula melalui faktor fundamental lainnya seperti inflasi dan suku bunga. Pertumbuhan nilai mata uang yang stabil dan rendah menunjukkan bahwa negara tersebut memiliki kondisi ekonomi yang relatif baik atau stabil sehingga tidak terlalu dikhawatirkan bahwa perbankannya sedang dalam kondisi yang bermasalah.

8. Penambahan periode pengamatan tahun 2104 menyebabkan terjadinya implikasi pada model temuan yaitu pada Nilai Tukar dan Net Interest Margin (NIM) yang tidak dapat digunakan untuk memprediksi potensi terjadinya kondisi bermasalah bank. Presentase keberhasilan prediksi terhadap kondisi bermasalah bank sebesar 96,7\% dengan adanya dua bank yang berdasarkan hasil observasi mengalami kerugian namun ternyata itu hanya one time event dan tidak berhubungan dengan kinerja bank secara umum. Variabel independen dalam model mampu menerangkan perubahan probabilitas terjadinya kondisi bermasalah bank sebesar $86,8 \%$, sedangkan $13,2 \%$ sisanya dipengaruhi oleh variabel lain di luar model sepertitingkat inflasi dan BI rate, serta jumlah M2 \& cadangan devisa, dan indikator fundamental lainnya.

\section{DAFTAR PUSTAKA}

Almilia, Luciana Spica dan Herdiningtyas, Winny. 2005. Analisis Rasio CAMEL Terhadap Prediksi Kondisi Bermasalah pada Lembaga Perbankan Perioda 2000-2002. Jurnal Ekonomi Akuntansi dan Keuangan, Vol.7, No.2, 131-147. 
Bank Indonesia. 2004. Surat Edaran Bank Indonesia Nomor 6/23/DPNP tanggal 31 Mei 2004 tentang Penilaian Tingkat Kesehatan Bank Umum. 2011. Surat Edaran Bank Indonesia Nomor 13/24/DPNP tanggal 25 Oktober 2011 tentang Penilaian Tingkat Kesehatan Bank Umum. . 2014. Kajian Stabilitas Keuangan tanggal 22 Maret 2014. Jakarta: Departemen Kebijakan Makroprudensial. 2011. Peraturan Bank Indonesia No 13/1/PBI/2011 tentang Penilaian Tingkat Kesehatan Bank. Jakarta: Bank Indonesia. 2014.Peraturan Bank Indonesia No 16/11/PBI/2014 tentang Pengaturan dan Pengawasan Makroprudensial. Jakarta: Bank Indonesia.

Biro Riset Infobank. 2014. Rating 120 Bank Versi Infobank. http://infobanknews.com diakses pada 29 Oktober 2014.

Ferdinand, Augusty. 2007. Metode Penelitian: Pedoman Penelitian Untuk Penulisan Skripsi, Tesis, dan Disertasi Ilmu Manajemen. Semarang : Badan Penerbit Universitas Diponegoro.

Hadad, M. D., Santoso, W., Sarwedi, Sukarno, H. 2004. Model Prediksi Kepailitan Bank Umum di Indonesia. Research Paper Direktorat Penelitian dan Pengaturan Perbankan. http://bi.go.id diakses tanggal 3 Novermber 2014.

Harianto, Farid dan Sudomo, Siswanto. 1998. Perangkat dan Teknik Analisis Investasi di Pasar Modal Indonesia. PT. Bursa Efek Jakarta.

Krisnawati, Dira Ayu. 2014. Analisis Faktor Penentu Profitabilitas Bank di Indonesia Dengan Metode Risk Based Bank Rating (Studi Pada Bank-bank Umum Go Public di Indonesia Periode 2008-2013). Skripsi. Semarang: Program Sarjana Universitas Diponegoro.

Otoritas Jasa Keuangan. 2014. OJK-Pedia. http://ojk.go.id diakses tanggal 29 Oktober 2014.

Prasetyo, Eka Adhi. 2011. Faktor-faktor yang Mempengaruhi Kondisi Financial Distress Perusahaan Perbankan Yang Listing Di BEI Tahun 2006-2008. Skripsi. Semarang: Program Sarjana Universitas Diponegoro.

Siamat, Dahlan. 2005. Manajemen Lembaga Keuangan: Kebijakan Moneter dan Perbankan. Edisi ke-1. Jakarta: Fakultas Ekonomi Universitas Indonesia. 
Spence, Michael. 1973. Job Market Signaling. The Quarterly Journal of Economics, Vol.87, No.3. http://jstor.org. Diakses tanggal 29 Oktober 2014.

Taswan. 2010. Manajemen Perbankan, Konsep, Teori dan Aplikasi. Edisi 2. Yogyakarta: UPP AMP YKPN.

Widarjono, Agus. 2009. Ekonometrika Pengantar dan Aplikasinya. Edisi III. Yogyakarta: EKONISIA. 